\title{
Regulation of Mcl-1 by constitutive activation of NF-kappaB contributes to cell viability in human esophageal squamous cell carcinoma cells
}

\author{
Haidan Liu ${ }^{1,2 \dagger}$, Jinfu Yang ${ }^{1,2+}$, Yunchang Yuan ${ }^{1 \dagger}$, Zhenkun Xia ${ }^{1}$, Mingjiu Chen ${ }^{1}$, Li Xie ${ }^{1}$, Xiaolong Ma ${ }^{1}$, Jian Wang ${ }^{1,2}$,
} Sufeng Ouyang ${ }^{1}$, Qin $\mathrm{Wu}^{1}$, Fenglei $\mathrm{Yu}^{1}$, Xinmin Zhou ${ }^{1}$, Yifeng Yang ${ }^{1}, \mathrm{Ya} \mathrm{CaO}^{3}$, Jianguo $\mathrm{Hu}^{1 *}$ and Bangliang Yin ${ }^{1{ }^{*}}$

\begin{abstract}
Background: Esophageal squamous cell carcinoma (ESCC) is one of the most lethal malignancies with a 5-year survival rate less than 15\%. Understanding of the molecular mechanisms involved in the pathogenesis of ESCC becomes critical to develop more effective treatments.

Methods: Mcl-1 expression was measured by reverse transcription (RT)-PCR and Western blotting. Human Mcl-1 promoter activity was evaluated by reporter gene assay. The interactions between DNA and transcription factors were confirmed by electrophoretic mobility shift assay (EMSA) in vitro and by chromatin immunoprecipitation (ChIP) assay in cells.

Results: Four human ESCC cell lines, TE-1, Eca109, KYSE150 and KYSE510, are revealed increased levels of Mcl-1 mRNA and protein compare with $\mathrm{HaCaT}$, an immortal non-tumorigenic cell line. Results of reporter gene assays demonstrate that human Mcl-1 promoter activity is decreased by mutation of kappaB binding site, specific NF-kappaB inhibitor Bay 11-7082 or dominant inhibitory molecule DNMIkappaBalpha in TE-1 and KYSE150 cell lines. Mcl-1 protein level is also attenuated by Bay 11-7082 treatment or co-transfection of DNMIkappaBalpha in TE-1 and KYSE150 cells. EMSA results indicate that NF-kappaB subunits $\mathrm{p} 50$ and p65 bind to human Mcl-1-kappaB probe in vitro. ChIP assay further confirm p50 and p65 directly bind to human Mcl-1 promoter in intact cells, by which regulates $\mathrm{Mcl}-1$ expression and contributes to the viability of TE-1 cells.
\end{abstract}

Conclusions: Our data provided evidence that one of the mechanisms of Mcl-1 expression in human ESCC is regulated by the activation of NF-kappaB signaling. The newly identified mechanism might provide a scientific basis for developing effective approaches to treatment human ESCC.

Keywords: Esophageal squamous cell carcinoma, Gene regulation, NF-kB, Mcl-1, Cell viability

\section{Background}

Human esophageal squamous cell carcinoma (ESCC) is one of the most frequently diagnosed carcinomas, ranked as the sixth leading cause of death from cancers worldwide. ESCC remains the most common histology and occurs at a very high frequency in China, South Africa, France and Italy [1]. Although modest advances have been made in chemotherapy for esophageal cancer, ESCC is still one of

\footnotetext{
* Correspondence: xys2133@163.com; yinb|@21cn.com

${ }^{\dagger}$ Equal contributors

${ }^{1}$ Department of Cardiothoracic Surgery, The Second Xiangya Hospital,

Central South University, 139 Renmin Road, Changsha, Hunan 410011, China Full list of author information is available at the end of the article
}

the most aggressive types of cancer with a 5-year survival rate less than $15 \%$. The underlying reasons for this disappointingly low survival rate remains to be greatly elucidated. Therefore, a better understanding of the molecular mechanisms of ESCC pathogenesis is expected to facilitate the development of novel therapies for this disease.

The Mcl-1 is an antiapoptotic gene of the Bcl-2 family members. Mcl-1 is overexpressed in many human tumor specimens, including hepatocellular carcinoma [2], pancreatic cancer [3], prostate cancer [4] and others [5]. Overexpression of Mcl-1 was found in malignant melanoma compared to benign nevi and increased expression of Mcl-1 was also observed by comparing primary and

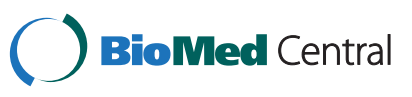

(c) 2014 Liu et al.; licensee BioMed Central Ltd. This is an open access article distributed under the terms of the Creative Commons Attribution License (http://creativecommons.org/licenses/by/2.0), which permits unrestricted use, distribution, and reproduction in any medium, provided the original work is properly cited. 
metastatic melanoma samples utilizing a tissue microarray [6]. In addition, frequent $M c l-1$ gene amplification was identified in lung, breast, neural and gastrointestinal cancers, through which cancer cells depend on the expression of this gene for survival [7]. A survey of antiapoptotic Bcl2 family member expression in breast, brain, colon, lung, ovarian, renal and melanoma cell lines revealed that $\mathrm{Mcl}-1$ mRNA is more abundant than $\mathrm{Bcl}-2$ or Bcl-xL [8]. These studies demonstrated that Mcl-1 plays a critical role in carcinogenesis and malignancy development in a broad range of human tumors, making it an attractive therapeutic target. However, the underlying mechanisms causing its elevation are not fully understood.

Expression of $\mathrm{Mcl}-1$ gene can be regulated at transcriptional level. Analysis of human $M c l-1$ gene 5 '-flanking promoter regions for potential transcription factor binding sites revealed consensus sequences including STAT, SRE, Ets, Sp1, CRE-BP [9]. Multiple intracellular signaling pathways and transcription factors have been confirmed to influence Mcl-1 expression, including PI3K/ Akt [10], Stat3 [11,12], CREB [10], Ets family members Elk-1 [13] and PU.1 [14]. In addition, putative binding sites for NF- $\mathrm{kB}$ were identified in the $\mathrm{Mcl}-1$ promoter region [9]. Previous studies demonstrated that inhibition of NF- $\mathrm{KB}$ activation by a novel NF- $\mathrm{kB}$ inhibitor V1810 [15] or Thiocolchicoside [16] accompanied by the downregulation of Mcl-1 expression. However, the underlying mechanistic link between NF-kB and Mcl-1 expression has not been clearly established in these studies. Moreover, although reports $[17,18]$ have revealed that p65 subunit of NF-kB involves in TRAIL induced expression of Mcl-1 in HCT-116 colon carcinoma cells [17] and the interaction of p65 with $\mathrm{N}$-a-Acetyltransferase 10 protein regulates Mcl-1 expression [18], the precise mechanism of Mcl-1 transcriptionally controlled by NF- $\mathrm{KB}$ family members is not fully elucidated. Therefore, a better understanding the role of this regulatory molecule in Mcl-1 expression in cancers may allow for the development of rational therapeutics that control Mcl-1 levels.

Transcripition factor NF-kB comprised of homo- and heterodimers of the RelA (p65), RelB, c-Rel, p50/p105 (NF-kB1) and p52/p100 (NF-kB2) polypeptides can both induce and repress gene expression by binding to discrete $\kappa \mathrm{B}$ elements in promoters and enhancers. The genes regulated by NF- $\mathrm{KB}$ include those controlling apoptosis, cell adhesion, proliferation, and inflammation. In most untransformed cell types, NF- $\kappa \mathrm{B}$ complexes are largely cytoplasmic by a family of inhibitory proteins known as inhibitors of NF-KB (IKBs) and therefore remain transcriptionally inactive [19]. Activation of NF- $k B$ typically involves the phosphorylation of I $\mathrm{K} B$ by the I $\mathrm{K} B$ kinase (IKK) complex, which results in ІкB degradation. This liberates NF- $\kappa B$ and allows it to translocate freely to the nucleus and binds to the $\mathrm{\kappa B}$ elements in the relevant downstream genes to activate a series of transcriptional events [19]. It has become apparent that aberrant activation of NF- $K B$ in human cancers are common [20]. Activation of NF- $\mathrm{kB}$ has been detected in tumor samples from patients, such as breast, colorectal, ovarian, pancreatic, prostate cancers and so forth $[21,22]$. Constitutive NF- $\mathrm{kB}$ activation has also reported in esophageal carcinoma tissues [22,23] and cell lines [24], implying NF- $\mathrm{BB}$ activation plays an important role in the tumorigenesis and development of human ESCC. Expression of Mcl-1 has been shown in human esophageal carcinoma cell lines CE81T/VGH [25] and KYSE450 [26]. We thus speculated that a direct link might exist between NF- $\mathrm{BB}$ and $\mathrm{Mcl}-1$ expression in human ESCC.

The present study was performed to determine whether Mcl-1 expression is modulated by NF- $\mathrm{KB}$ signal pathway in human ESCC. Using human ESCC cell lines as models, reporter gene assays demonstrate that human $\mathrm{Mcl}-1$ promoter activity is decreased by mutation of $\kappa B$ site, specific NF- $\mathrm{BB}$ inhibitor Bay11-7082 or dominant inhibitory molecule DNMIкB $\alpha$ in TE-1 and KYSE150 cells. Mcl-1 level is attenuated by Bay11-7082 treatment or co-transfection of DNMI $\kappa \alpha$ in TE-1 and KYSE150 cells. NF-kB subunits p50 and p65 are further confirmed bound to Mcl-1-кB probe in vitro by EMSA assay and directly bound to human Mcl-1 promoter in intact cells by ChIP assay, respectively. Our data provided evidence that one of the regulatory mechanisms by which Mcl-1 expression in human ESCC is by binding of p50 and p 65 to $\mathrm{kB}$ site within human $\mathrm{Mcl}-1$ promoter. This NF-kB mediating Mcl-1 expression also contributes to the viability of TE-1 cells. In conclusion, the newly identified mechanism might provide a scientific basis for developing effective approaches to treatment human ESCC.

\section{Methods}

\section{Cell lines and culture}

Human esophageal carcinoma cell lines TE-1 and Eca109 were purchased from Cell Bank of Chinese Academy of Sciences, Shanghai, China. Human esophageal carcinoma cell lines KYSE150 and KYSE510 were kindly provided by Dr. Qian Tao from The Chinese University of Hong Kong, HongKong, China. Immortalized human keratinocyte cell line $\mathrm{HaCaT}$ derived from human adult trunk skin was previous described $[27,28]$. TE-1, Eca109, KYSE150 and KYSE510 cells were cultured in RPMI 1640 medium (Invitrogen, Carlsbad, CA) supplemented with $10 \%$ fetal bovine serum, 100 units $/ \mathrm{ml}$ penicillin and $100 \mathrm{mg} / \mathrm{ml}$ streptomycin. $\mathrm{HaCaT}$ was cultured in DMEM medium (Invitrogen, Carlsbad, CA) containing $10 \%$ fetal bovine serum and antibiotics as described above. All cell lines were incubated at $37^{\circ} \mathrm{C}$ in a humidified atmosphere containing 5\% $\mathrm{CO} 2$. 


\section{Chemicals and cell treatments}

The specific NF-kB inhibitor Bay11-7082 (Calbiochem, Darmstadt, Germany) was prepared as a stock solution of $20 \mathrm{mM}$ in DMSO (Sigma, St. Louis, MO). Subconfluent cells were treated with the compound at indicated concentrations for an indicated time. Detailed treatment procedures were described in figure legends. The final concentration of DMSO in the culture media was kept less than $0.1 \%$ which had no significant effect on the cell growth. Vehicle controls were prepared for all treatments.

\section{Plasmids}

The pGL2-Mcl-1-kBwt (Addgene plasmid 19132) which contains a 325 bp long human $\mathrm{Mcl}-1$ promoter fragment including NF- $\kappa \mathrm{B}$ binding-site (GGGGTCTTCC) and the pGL2-Mcl-1-kBmt (Addgene plasmid 19133) in which the $\kappa \mathrm{B}$ site sequence GGGGTCTTCC being changed to GTTGTCTTCC were constructed by Dr. El-Deiry [17] and obtained through Addgene (Cambridge, MA). The pGL2-Basic vector was purchased from Promega (Madison, WI). The pGL3-Basic vector and pGL3-NF-кB-Luc were the same as described previously [29,30]. Expression plasmid of dominant negative mutant of IкB $\alpha$ (pcDNA3-DNMIкB $\alpha$ ) [30] and the pcDNA3.1 empty vector [31] were identical to those used previously. The human full-length Mcl-1 expression vector pCMV6-APuro-Mcl and pCMV6-A-Puro empty vector were kindly provided by Dr. Chengchao Shou [18].

\section{Transfection and luciferase reporter assays}

Cells were cultured in 24-well plates at a density of $1 \times$ $10^{5}$ per well overnight and transfected with Lipofectamine $^{\text {TM }} 2000$ (Invitrogen, Carlsbad, CA) according to manufacturer's instructions. In luciferase assay for NF$\kappa B$ transactivation, each transfection contained $800 \mathrm{ng} /$ well of pGL3-Basic or pGL3-NF-kB-Luc together with 40 ng/well of internal control pRL-SV40 (Promega, Madison, WI) (Total DNA $840 \mathrm{ng} /$ well). $24 \mathrm{~h}$ after transfection, cells were either left untreated (DMSO) or treated with $20 \mu \mathrm{M}$ Bay11-7082 for $12 \mathrm{~h}$. Cells were harvested at $36 \mathrm{~h}$ after transfection and lysates were analyzed for luciferase activity using the Dual Luciferase Reporter assay (Promega, Madison, WI) with a GloMax ${ }^{\text {TM }}$ Microplate Luminometer (Promega, Madison, WI). In luciferase assay for the $\mathrm{Mcl}-1$ promoter, each transfection contained $400 \mathrm{ng} /$ well of pGL2-Basic, pGL2-Mcl-1kBwt or pGL2-Mcl-1-kBmt together with $400 \mathrm{ng} /$ well of pcDNA3.1 or pcDNA3-DNMIкB $\alpha$ expression plasmid. Each transfection contained $40 \mathrm{ng} /$ well of pRL-SV40 as internal control (Total DNA $840 \mathrm{ng} /$ well). $24 \mathrm{~h}$ after transfection, cells were either left untreated (DMSO) or treated with $20 \mu \mathrm{M}$ Bay11-7082 for $12 \mathrm{~h}$. Cells were harvested at $36 \mathrm{~h}$ after transfection and lysates were analyzed as described above. The pRL-SV40 was co-transfected in all experiments to correct the variations in transfection efficiency. The data represent the mean \pm S.D. of at least two independent experiments performed in triplicate.

\section{RNA interference}

TE-1 cells were grown in 6-well plates at a density of $3 \times 10^{5}$ cells per well overnight. Cells reached 60-70\% confluency on the day of transfection and were transfected with a p50 (sc-29407; 100 pmol), a p65 (sc-29410; 100 pmol) or a scrambled control (sc-37007; 100 pmol) siRNA (all from Santa Cruz Biotechnology) using HiPerFect transfection reagent (Cat no: 301705, Qiagen) for $72 \mathrm{~h}$ according to the manufacturer's instructions. Cells were harvested for protein extraction and immunoblotting to confirm p50 or p65 knockdown.

\section{Cell viability assay}

Cell viability assays were performed using the 4-[3-(4iodophenyl)-2-(4-nitrophenyl)-2H-5-tetrazolio]-1,3-benzene disulfonate (WST-1) assay kit (Roche, Indianapolis, IN) according to the manufacturer's instructions. The assay is based on the cleavage of WST-1 to formazan dye by cellular mitochondrial dehydrogenases. Because cleavage of WST-1 to formazan dye occurs only in viable cells, the amount of dye produced, measured in OD values, directly corresponds with the number of viable cells present in the culture. Briefly, TE-1 cells were firstly transfected with the control, p50 or p65 siRNA in sixwell plates as described above. To investigate whether reintroduction of Mcl-1 restored cell viability, $24 \mathrm{~h}$ following the first transfection, a second transient transfection was carried out to ectopically express Mcl-1. Each transfection contained $2 \mu \mathrm{g}$ pCMV6-A-Puro empty vector or pCMV6-A-Puro-Mcl construct using SuperFect transfection reagent (Cat no: 301305, Qiagen) according to the manufacturer's instructions. At $24 \mathrm{~h}$ posttransfection, cells were trypsinized, an aliquot of cells was maintained in six-well plate, harvested at $120 \mathrm{~h}$ after NF- $\kappa$ B subunit siRNA transfection and analyzed the Mcl-1 levels by Western blotting. The remainder was transferred as six replicates to 96-well plates at a concentration of $2.5 \times 10^{3}$ cells per well in $100 \mu \mathrm{l}$ of complete RPMI 1640. After culturing for another 24, 48, $72 \mathrm{~h}$ (i.e. $72 \mathrm{~h}, 96 \mathrm{~h}, 120 \mathrm{~h}$ after each siRNA transfection, respectively), $10 \mu \mathrm{l}$ of WST-1 was added to each well and cells incubated for $2 \mathrm{~h}$ at $37^{\circ} \mathrm{C}$. The cellular reduction of WST-1 to formazan and its absorbance were measured at $450 \mathrm{~nm}$.

\section{Protein preparation and western blotting}

Cultured cells were harvested and whole cell lysates were prepared according to the method previously described [30]. Nuclear extracts were prepared using a Nuclear Extract kit (Cat. no. 40010, Active Motif, Carlsbad, 
CA) following the manufacturer's instructions. Protein concentration was determined using the BCA Assay Reagent (Cat. no. 23228, Pierce, Rockford, IL). Western blotting was performed as previously described [30]. The following antibodies were used for immunodetection with appropriate dilutions: Mcl-1 (sc-819, 1:1000), p50 (sc-114, 1:1000), p52 (sc-298, 1:1000), p65 (sc-8008, 1:1000), c-Rel (sc-272, 1:1000), RelB (sc-226, 1:1000) and GAPDH (sc-47724, 1:2000) (all from Santa Cruz, CA); Histone H3 (\#9715, 1:1000) were purchased from Cell Signaling Technology (Beverly, MA); $\beta$-actin (A5316, 1:5000) was purchased from Sigma (St. Louis, MO).

\section{mRNA extraction and reverse transcription-polymerase chain reaction (RT-PCR)}

Total RNA was extracted using Trizol reagent (Invitrogen, Carlsbad, CA). First-strand cDNA was synthesized from $2 \mu \mathrm{g}$ of total RNA using the Reverse Transcription System Kit (Cat. No. A3500, Promega, Madison, WI). The resulted cDNA was subjected to PCR $\left(94^{\circ} \mathrm{C}\right.$ for $5 \mathrm{~min}$ followed by 34 cycles of $94^{\circ} \mathrm{C}$ for $30 \mathrm{~s}, 58^{\circ} \mathrm{C}$ for $30 \mathrm{~s}, 72^{\circ} \mathrm{C}$ for $40 \mathrm{~s}$, and an extension for $10 \mathrm{~min}$ at $72^{\circ} \mathrm{C}$ ) using primers designed for human Mcl-1 [11]: sense, 5'-cggcagtcgctggagattat-3' and antisense, 5 ' -gtggtggtggttggtta-3', yield a 573-bp product; or for GAPDH: sense, $5^{\prime}$-caaagttgtcatggatgacc-3' and antisense, 5' -ccatggagaaggctgggg-3', yield a 195-bp product. Real-time RT-PCR experiments were done in triplicate as described previously [32] and the primers used were as following [33]: forward 5 ' -gggcaggattgtgactctcatt- 3 '; reverse $5^{\prime}$-gatgcagctttcttggtttatgg-3'. The relative Mcl-1 mRNA expression levels were calculated according to the comparative CT $(\Delta \Delta \mathrm{CT})$ method after normalizing to GAPDH expression. Semiquantitive RT-PCR products were separated on $1.5 \%$ agarose gels and visualized with ethidium bromide. The identity of Mcl-1 PCR product was confirmed by direct sequencing after purification.

\section{Electrophoretic mobility shift assays}

Nuclear proteins from cultured cells were prepared and protein concentration was determined as described above. EMSA was performed using the LightShift ${ }^{\text {тा }}$ Chemiluminescent EMSA Kit (Cat. No. 20148, Pierce, Rockford, IL) following the manufacturer's instructions. The reaction mixtures $(20 \mu \mathrm{l})$ containing $8 \mu \mathrm{g}$ nuclear extracts were incubated with $2 \mathrm{nM}$ of biotin-labeled double-stranded oligonucleotide probes in reaction buffer for $20 \mathrm{~min}$ at room temperature. Samples were subjected to electrophoresis in $5 \%$ nondenaturing polyacrylamide gel and transferred to Biodyne $^{\text {тм }}$ BNylon membrane (Cat. No. 77016, Pierce, Rockford, IL). For competition analyses, 100-fold excess of unlabeled probes were included in the binding reaction. For antibody supershift experiments, the reaction mixtures were preincubated with $2 \mu \mathrm{g}$ of p50 (sc-8414X), p52 (sc298X), p65 (sc-8008X), c-Rel (sc-272X), RelB (sc-226X) or rabbit IgG (sc-2027) antibody (all from Santa Cruz, CA) for $30 \mathrm{~min}$ at room temperature. Biotin-labeled doublestranded oligonucleotides were used as probes listed below: wild-type NF- $\mathrm{B}$ Consensus binding sequence: 5 '-agttgaggggactttccaggc-3' [34]; wild-type Mcl-1-kB binding sequence: $5^{\prime}$-ggagtcggggtcttccccagtttt-3', corresponding to the nucleotides of the human $\mathrm{Mcl}-1$ promoter. Unlabeled doublestranded oligonucleotides used for competition analyses were: wild-type NF-kB consensus binding sequence: 5'agttgaggggactttcccaggc-3'; mutated NF- $\mathrm{kB}$ consensus binding sequence: 5'-agttgaggagatctggccaggc-3' [34]; mutant Mcl-1-кB binding sequence: 5' -ggagtcgttgtcttccccagtttt-3'; The AP-1 consensus probe was used as a nonspecific competitor for NF-kB: 5'-cgcttgatgagtcagccggaa-3' [35]. The probes were commercially synthesized by TaKaRa Bio Inc. (Dalian, China). Binding sites were indicated in italics type and mutations were shown in bold type. The mutated nucleotides for NF-kB binding site of human $\mathrm{Mcl}-1$ promoter in EMSA were identical to those of the mutated sequences in the reporter construct.

\section{Chromatin immunoprecipitation (ChIP) assay}

ChIP was performed using the ChIP assay kit (Upstate Biotechnology, Lake Placid, NY) as previously described [30]. Antibodies used for immunoprecipitation were: p50 (sc-8414X), p52 (sc-298X), p65 (sc-8008X), c-Rel (sc272X), RelB (sc-226X) and rabbit IgG (sc-2027) (all from Santa Cruz, CA). $2 \mu \mathrm{g}$ of each antibody was used for each immunoprecipitation. The following primers were used in the ChIP assays: human $\mathrm{Mcl}-1$ promoter including the NF- $\mathrm{kB}$ binding region, 5 ' -cacttctcacttccgcttcc-3' and $5^{\prime}$-ttctccgtagccaaaagtcg-3' (200 bp).

\section{Statistical analysis}

Statistical analysis was done with the statistical software program SPSS ver.12.0. Results expressed as mean \pm S.D. were analyzed using the Student's $t$ test. Differences were considered significant when $\mathrm{P}$ value was $<0.05$.

\section{Results}

Expression of Mcl-1 mRNA and protein in human esophageal squamous cell carcinoma cell lines

To investigate the expression patterns of Mcl-1 in human ESCC cell lines, Mcl-1 expression was first measured by Western blotting. As shown in Figure 1A, four human esophageal carcinoma cell lines, including TE-1, Eca109, KYSE150 and KYSE510 revealed increased levels of Mcl-1 protein compare with an immortal non-tumorigenic keratinocyte $\mathrm{HaCaT}$ cell line [27], which was used as a normal control [36,37] for Mcl-1 expression. The Mcl-1 protein levels among these esophageal carcinoma cell lines were similar (Figure 1A). In addition, semi-quantitative RT-PCR was performed to analyze the $\mathrm{Mcl}-1$ mRNA expression in these cell lines. The RT-PCR results indicated increased 

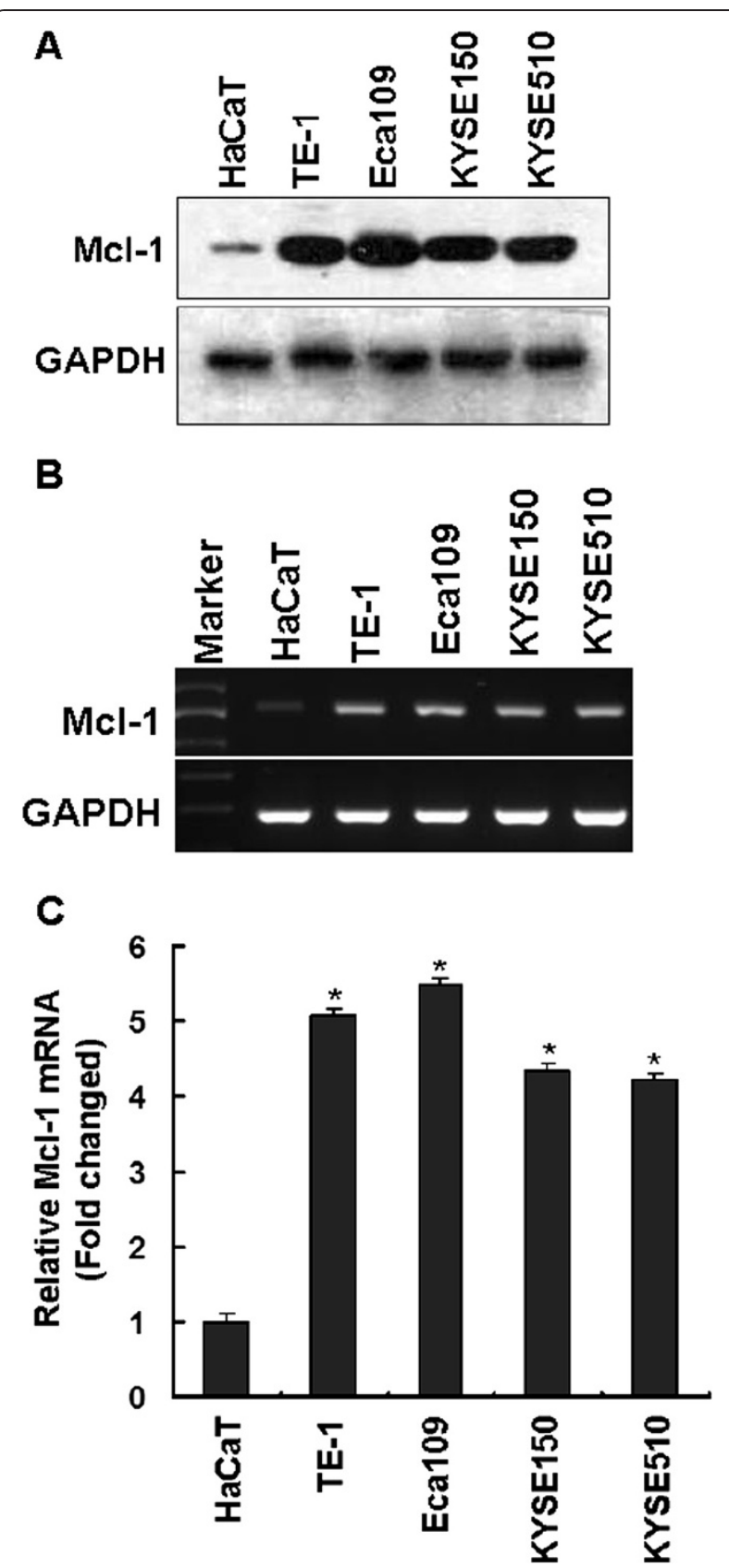

Figure 1 Expression of Mcl-1 protein and mRNA in human esophageal squamous cell carcinoma cell lines. (A) Expression of Mcl-1 protein in various esophageal carcinoma cell lines. Whole cell lysates of TE-1, Eca109, KYSE150 and KYSE510 as well as HaCaT cell lines were subjected to immunoblotting analysis with anti-Mcl-1 antibody. GAPDH was used as a loading control. (B) Total RNA was isolated from above-mentioned cell lines and subjected to RT-PCR, using specific primers designed to amplify $\mathrm{MCl}-1$ and GAPDH mRNAs. GAPDH was used as a loading control. (C) Mcl-1 mRNA expression levels of TE-1, Eca109, KYSE150 and KYSE510 as well as $\mathrm{HaCaT}$ cell lines were analyzed by quantitative real-time RT-PCR. The Mcl-1 mRNA level of HaCaT cells was normalized to a value of 1 . Fold-change in mRNA levels was shown. Data are presented as the mean \pm S.D. of two independent experiments performed in triplicate. Statistical significance: ${ }^{*}, \mathrm{p}<0.01$, compared with $\mathrm{HaCaT}$ cells. expression of $\mathrm{Mcl}-1$ mRNA levels in four human ESCC cell lines compared with that in $\mathrm{HaCaT}$ cells (Figure 1B), which was in agreement with the observations in the immunoblotting analysis. We also performed quantitative real-time RT-PCR to compare mRNA levels of $M c l-1$ in these cell lines. As shown in Figure 1C, higher mRNA levels of $\mathrm{Mcl}-1$ in TE-1, Eca109, KYSE150 and KYSE510 cells, about a 5fold increase of $M c l-1$ for each cell line compared with $\mathrm{HaCaT}$ cells. The observations that Mcl-1 protein levels corresponding exactly with its mRNA levels suggested Mcl1 expression was regulated, at least in part, at transcriptional level in human ESCC cells.

NF-KB is constitutively activated in Mcl-1-expressing human esophageal squamous cell carcinoma cell lines

NF- $\mathrm{kB}$ has been shown to play a role in TRAIL-induced Mcl-1 expression in HCT-116 colon cancer cells [17] and the interaction of p65 subunit with Naa10p reportedly regulates Mcl-1 expression [18], However, whether $\mathrm{NF}-\mathrm{kB}$ is involved in Mcl-1 expression in human ESCC cells remains to be clarified. To address this issue, we initially evaluated whether NF- $\mathrm{kB}$ is constitutively activated in Mcl-1-expressing human ESCC cells. NF-кB activation as measured by nuclear accumulation has been observed in a wide variety of solid tumors [22]. Therefore, nuclear extracts of TE-1, Eca109, KYSE150, KYSE510 and $\mathrm{HaCaT}$ cell lines and the levels of NF- $\mathrm{KB}$ subunits in nucleus were estimated. Histone $\mathrm{H} 3$ level served as a loading control for nuclear protein [38]. The levels of NF-кB subunits in nuclear extracts of four ESCC cell lines were markedly higher than those in $\mathrm{HaCaT}$ cells, suggested that NF-kB is highly constitutively activated in these ESCC cell lines detected. The results indicated that TE-1 cell line displayed relatively high levels of NF-кB subunit p50 and p52. The expression patterns of NF- $\mathrm{kB}$ subunit p65, c-Rel and RelB were similar in other three esophageal carcinoma cell lines (Figure 2). The distinctive patterns for constitutively activated NF- $\mathrm{kB}$ subtypes in different ESCC cell lines suggested that NF- $\mathrm{kB}$ subunits might play a specific role in regulating Mcl-1 in different esophageal carcinoma cell lines. These results led to the conclusion that the NF$\mathrm{\kappa B}$ pathway is constitutively activated in Mcl-1-expressing human ESCC cell lines.

The role for NF-KB signaling pathway in regulating the MCl-1 promoter activity in various human esophageal squamous cell carcinoma cell lines

To examine whether NF- $\mathrm{kB}$ activated transcription from the promoter of human $\mathrm{Mcl}-1$ gene in Mcl-1-expressing ESCC cell lines, different series of human esophageal carcinoma cell lines TE-1, Eca109 and KYSE150 were transiently transfected with the luciferase reporter plasmid containing a $325 \mathrm{bp}$ long human $\mathrm{Mcl}-1$ promoter fragment. As seen in Figure 3A, transfection of the pGL2- 


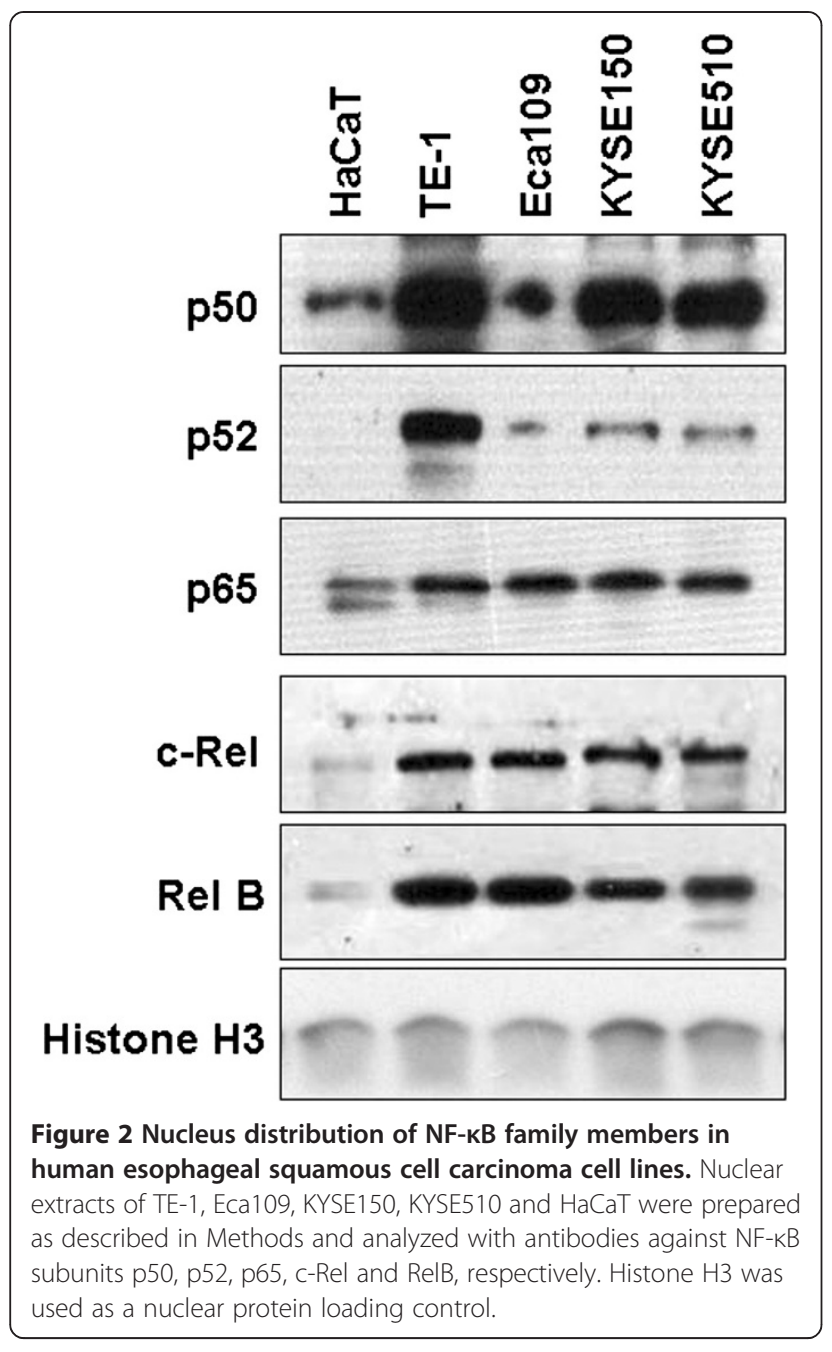

Mcl-1-kBwt generated higher luciferase activity than that of the pGL2-Basic construct, indicated that high transcriptional activity of human $\mathrm{Mcl}-1$ promoter in three Mcl-1expressing ESCC cell lines tested. However, with a promoter construct mutated at the $\mathrm{\kappa B}$ site, the loss of $\mathrm{Mcl}-1$ promoter activity was observed in TE-1 and KYSE150 cells (Figure 3A). Dominant negative mutants of $\mathrm{I} \kappa \mathrm{B} \alpha$ $(\mathrm{DNMI} \kappa \mathrm{B} \alpha)$, a truncant mutant with a deletion of 71 amino acids at the $\mathrm{N}$ terminus of $\mathrm{I} \kappa \mathrm{B} \alpha$, can competitively inhibit the activation of NF-kB was used to block NF- $\mathrm{kB}$ activation as described previously [30]. Expression of DNMIkB $\alpha$ significantly inhibited the $\mathrm{Mcl}-1$ promoter activity in TE-1 and KYSE150 cells (Figure 3A). Furthermore, compared with their respective DMSO control, treatment with $20 \mu \mathrm{M}$ Bay11-7082, a specific NF-kB inhibitor, resulted in the $\mathrm{Mcl}-1$ promoter activity drastically curtailed in both TE-1 and KYSE150 cells. The activity of the $\mathrm{Mcl}-1$ promoter with mutated NF- $\mathrm{KB}$ site was essentially unaffected by inhibitor treatment (Figure 3A). NF$\mathrm{\kappa B}$ transcriptional activities in both TE-1 and KYSE150 cell lines have also been estimated by using an NF-kB- driven luciferase reporter. The results indicated that NF$\kappa \mathrm{B}$-driven luciferase reporter show an increased transcriptional activity in both TE-1 and KYSE150 cells compared with the vector control (Figure 3B). Bay11-7082 (20 $\mu \mathrm{M})$ significantly attenuated the increased transcriptional activity of NF-kB-driven luciferase reporter in these two cell lines, thus confirmed the efficiency of Bay11-7082 as an NF- $\mathrm{kB}$ inhibitor (Figure 3B). Notably, the increased transcriptional activity of the $\mathrm{Mcl}-1$ promoter observed in Eca109 cells remained unchanged by the above three strategies (Figure 3A). Taken together, these results provide consistent evidence that the involvement of NF- $\mathrm{kB}$ pathway in the $\mathrm{Mcl}-1$ promoter transcriptional activity in various human ESCC cells.

NF-KB signaling pathway contributes to $\mathrm{Mcl}-1$ expression in various human esophageal squamous cell carcinoma cell lines

We further confirm whether NF- $\mathrm{kB}$ is involved in Mcl-1 expression in human ESCC cells. Bay11-7082 was firstly used to investigate the effect of NF- $\mathrm{kB}$ activation on Mcl-1 induction. Treatment of TE-1 cells with the inhibitor resulted in a dose-dependent attenuation of Mcl1 induction (Figure 4A). Similar results were obtained from KYSE150 cells treated with various concentrations of Bay11-7082 (Figure 4B). DNMIkB $\alpha$ was further used to test the role of NF- $\mathrm{BB}$ pathway in regulating $\mathrm{Mcl}-1$ expression. As verified by Western blotting analysis, expression of DNMIkB $\alpha$ in TE-1 (Figure 4C) or KYSE150 (Figure 4D) cells led to a significant decrease of Mcl-1 induction compared with the vector control. The results suggested that NF- $\mathrm{KB}$ pathway is involved in Mcl-1 expression in TE-1 and KYSE150 cells.

\section{Binding of transcription factor NF-KB family members to human $\mathrm{Mcl}-1$ promoter}

To ascertain whether NF- $\mathrm{B}$ transcription factor can bind the NF-kB site in human $\mathrm{Mcl}-1$ promoter, EMSA was performed with an oligonucleotide probe containing the putative NF-kB binding sequence derived from human $\mathrm{Mcl}-1$ promoter. Three DNA-protein complexes were evident with nuclear extracts from TE-1 cells, labeled bands 1, 2 and 3, respectively (Figure 5A). To further confirm whether these three bands are specific for the NF- $\kappa B$ complexes, a competition assay was performed. The band 3 of complex could be completely abolished by a 100-fold excess unlabeled wild-type Mcl$1-\kappa \mathrm{B}$ probe (lane 3) or NF- $\mathrm{BB}$ consensus oligonucleotide (lane 5), but not by 100-fold excess unlabeled mutant Mcl-1-kB probe (lane 4) or 100-fold excess unrelated AP-1 consensus oligonucleotide (lane 6). In contrast, two upper bands ( 1 and 2 ) were not competed away by either unlabeled wild-type Mcl-1-kB oligonucleotide (lane 3) or $\mathrm{kB}$ consensus probe (lane 5) even at a 100- 

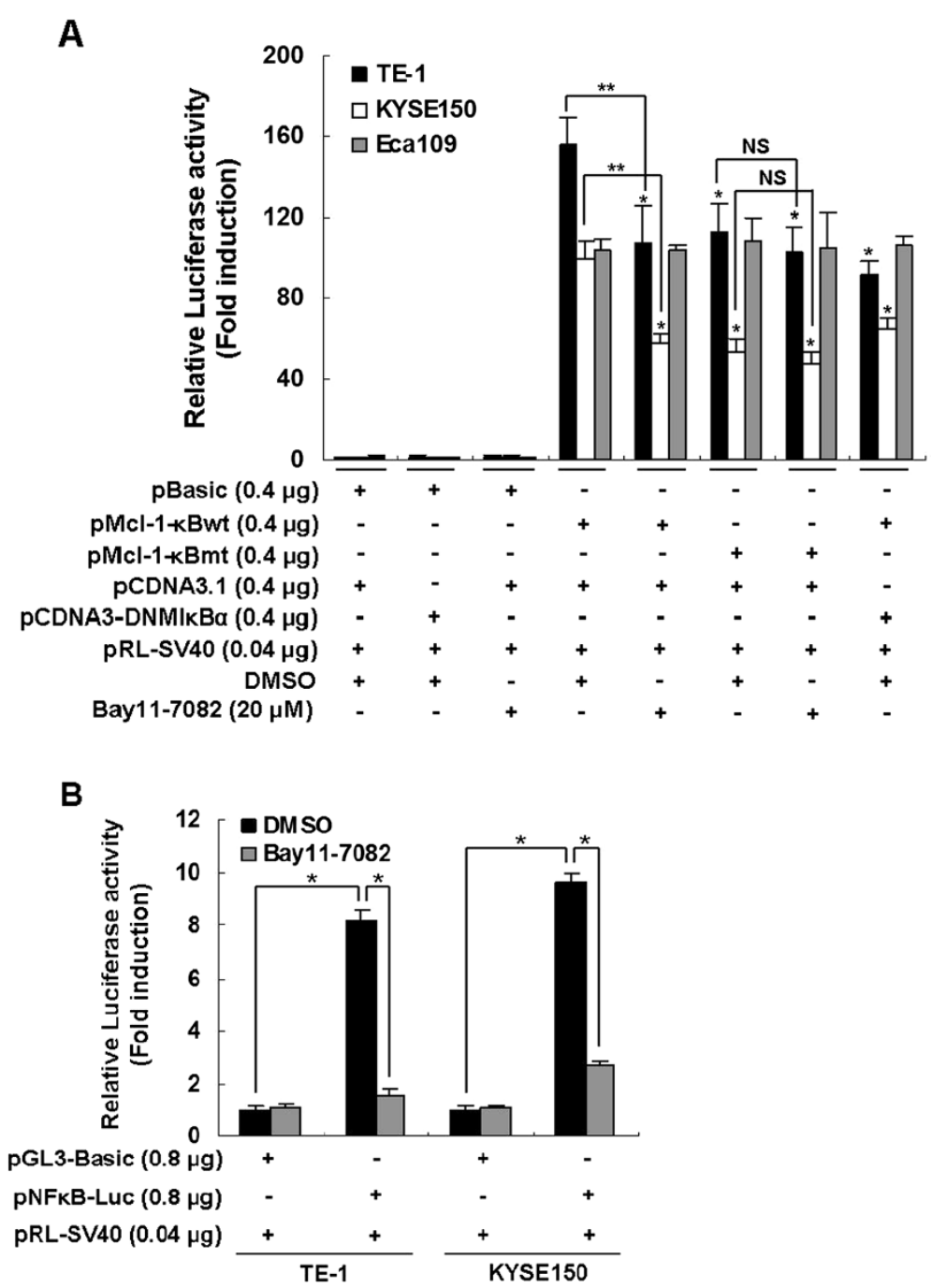

Figure 3 The role for NF-KB signaling pathway in regulating transcriptional activity of human Mc1-1 promoter in various human esophageal squamous cell carcinoma cell lines. (A) TE-1, KYSE150 or Eca109 cells were transfected of pGL2-Basic, pMcl-1-kBWt or pMcl-1-kBmt together with pCDNA3.1 empty vector or pCDNA3-DNMIKBa plasmid. The pRL-SV40 was co-transfected in all experiments to correct the variations in transfection efficiency. Transfected cells were incubated for $24 \mathrm{~h}$ and then treated with DMSO or $20 \mu \mathrm{M}$ Bay 11-7082 for an additional $12 \mathrm{~h}$ after which the activities of firefly and Renilla luciferase were monitored by dual luciferase reporter assay. The relative luciferase activity normalized to the value of Renilla luciferase activity. The Mcl-1 promoter activities were expressed as fold induction of their respective pGL2-Basic-transfectedcells treated with DMSO. Data are shown as means \pm S.D. of at least two independent experiments performed in triplicate. Statistical significance: ${ }^{*} \mathrm{p}<0.05$, compared with their respective pMcl-1-KBwt-transfected-cells treated with DMSO. ${ }^{* *} p<0.05$, pMcl-1-kBwt-transfected-cells treated with DMSO versus pMcl-1-kBwt-transfected-cells treated with Bay11-7082. NS, no significant difference between pMcl-1-kBmt-transfected-cells treated with DMSO and pMcl-1-KBmt-transfected-cells treated with Bay11-7082. (B) Effects of Bay11-7082 on the transactivation activity of NF-kB in TE-1 and KYSE150 cell lines. TE-1 or KYSE150 cells were transient transfected with PGL3-Basic vector or PGL3-NF-KB-Luc plasmid and luciferase reporter assay were performed as described in Methods. The relative luciferase activity normalized to the value of Renilla luciferase activity. NF-kB-driven luciferase activities were expressed as fold induction of their respective PGL3-Basic-transfected-cells treated with DMSO. Data are presented as the mean \pm S.D. of two independent experiments performed in triplicate. Statistical significance: *, $p<0.01$.

fold molar excess. These results, which were similar to previously published report [39], suggested that the band 3 is specific for the NF-kB complex. The observation that the Mcl-1-kB oligonucleotide can bind non-NF-kB specific complexes as well might due to other protein(s) present in the nuclear extracts that also bind the NF-kB sequence of the oligonucleotide [40]. To identify which components of NF- $\mathrm{kB}$ contribute to this binding activity, supershift analysis was performed with nuclear extracts from TE-1 cells. In the presence of antibodies against NF- $\mathrm{kB}$ subunits p50, p52, p65, c-Rel, and RelB, the results revealed that the addition of an antibody against p50, p52 or p65 caused a substantial reduction in binding (lanes 7, 8 and 9). The intensity of the DNA-protein 

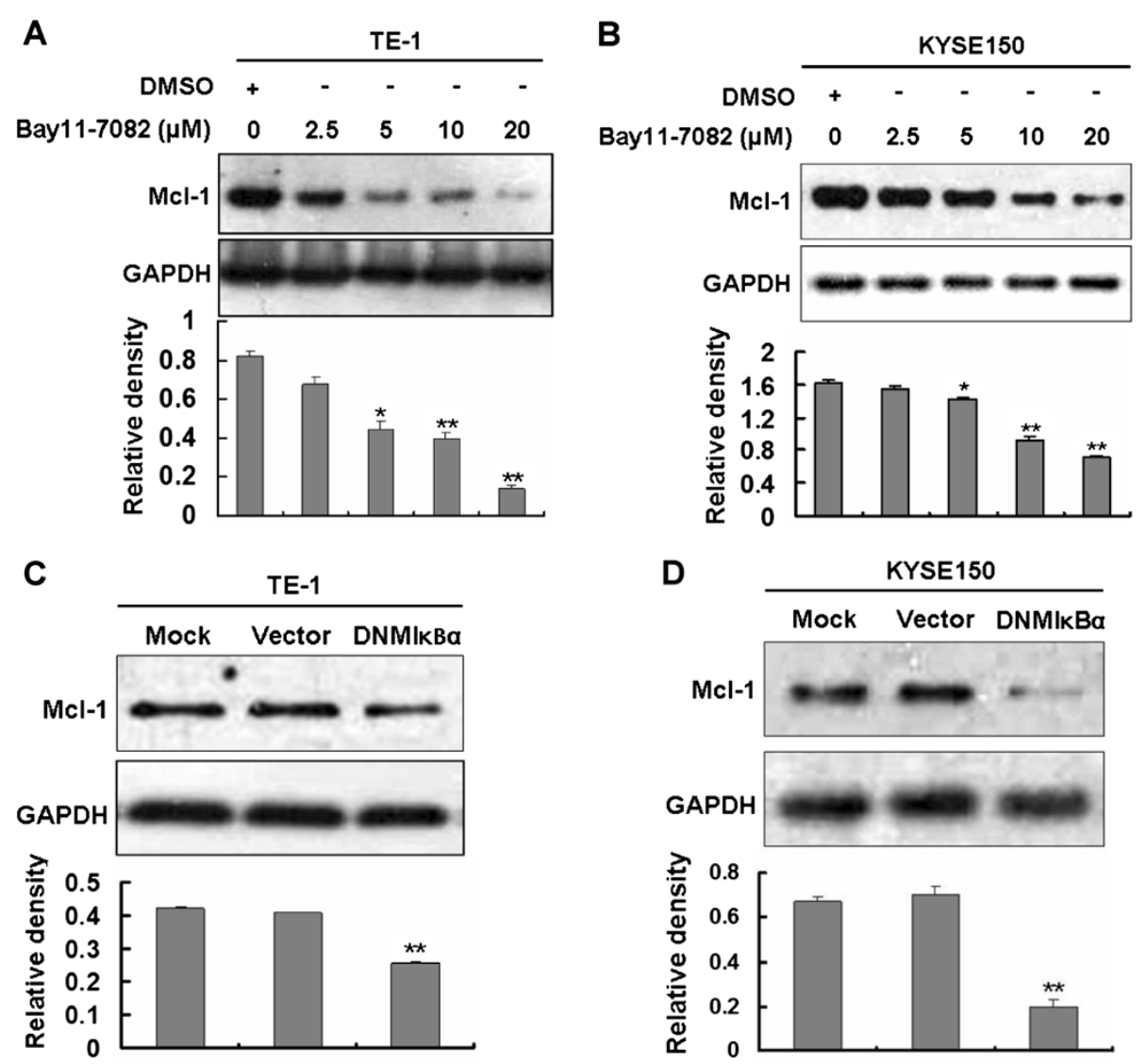

Figure 4 Attenuation of $\mathrm{Mcl}-1$ expression by NF-кB inhibitor or dominant negative mutant of IKBa in various human esophageal squamous cell carcinoma cell lines. (A, B) Inhibition of NF-KB pathway by NF-KB-specific inhibitor Bay11-7082 prevented Mcl-1 expression in TE-1 (A) and KYSE150 (B) cell lines. TE-1 or KYSE150 cells were treated with indicated concentrations of DMSO or Bay11-7082 for $24 \mathrm{~h}$, whole cell lysates were harvested. Mcl-1 was determined by Western blotting. GAPDH was used as a loading control. Data shown are representative of at least two independent experiments. Statistical significance: * $p<0.05$ and ${ }^{* *} p<0.01$, compared with the DMSO control. (C, D) Expression of dominant negative mutant of $\mathrm{IKBa}_{\mathrm{K}}\left(\mathrm{DNM} \mathrm{IKBa}_{\mathrm{K}}\right.$ ) decreased Mcl-1 protein level in TE-1 (C) and KYSE150 (D) cell lines. TE-1 or KYSE150 cells seeded in 12-well plate were untransfected (Mock), transfected with $1600 \mathrm{ng} /$ well pcDNA3.1 empty vector or $1600 \mathrm{ng} /$ well DNMIkBa expression plasmid using Lipofectamine 2000 according to manufacturer's instructions. Cells were harvested at $24 \mathrm{~h}$ after transfection and subjected to Western blotting analysis with anti-Mcl-1 antibody. GAPDH was used as a loading control. Data shown are representative of at least two independent experiments. Statistical significance: ${ }^{* *} \mathrm{p}<0.01$, compared with the pcDNA3.1 empty vector-transfected control.

complex was slightly depleted by c-Rel (lane 10) while antibody against RelB had no effect on binding (lane 11). IgG control also showed no effect on the intensity of the complex (lane 12). These data demonstrated that binding of these antibodies prevents association with the labeled probe. The decreases in band intensity suggested the presence of these transcription factors in the complex, which indicate that p50, p52 and p65 are the major NF- $\mathrm{kB}$ subunits binding to the human Mcl-1- $\mathrm{kB}$ probe in vitro.

To determine whether transcription factor NF- $\mathrm{kB}$ actually bind to human $M c l-1$ promoter in intact cells, we analyzed the fragment that spans the NF- $\mathrm{kB}$ binding region within human $\mathrm{Mcl}-1$ promoter using a chromatin immunoprecipitation assay (ChIP). The sheared cross- linked chromatin of TE-1 cells was immunoprecipitated by antibodies specific for NF-kB subunits p50, p52, p65, c-Rel and RelB. An IgG antibody was used as a nonspecific control. The precipitated chromatin DNA was then amplified by PCR using primers specific for NF- $\mathrm{kB}$ binding site of human $\mathrm{Mcl}-1$ gene, which produced 200-bp amplicons that could be observed with the positive control (input chromatin) and when the chromatin was precipitated with antibodies for p50 and p65, respectively. No amplification was observed with two negative controls (no chromatin and IgG) (Figure 5B). The ChIP results indicated that NF- $\mathrm{kB}$ subunits p50 and p65 can exert their regulatory function through directly binding to the NF- $\mathrm{kB}$ site of human $\mathrm{Mcl}-1$ promoter and finally regulating Mcl-1 expression in TE-1 cells. Overall, the 


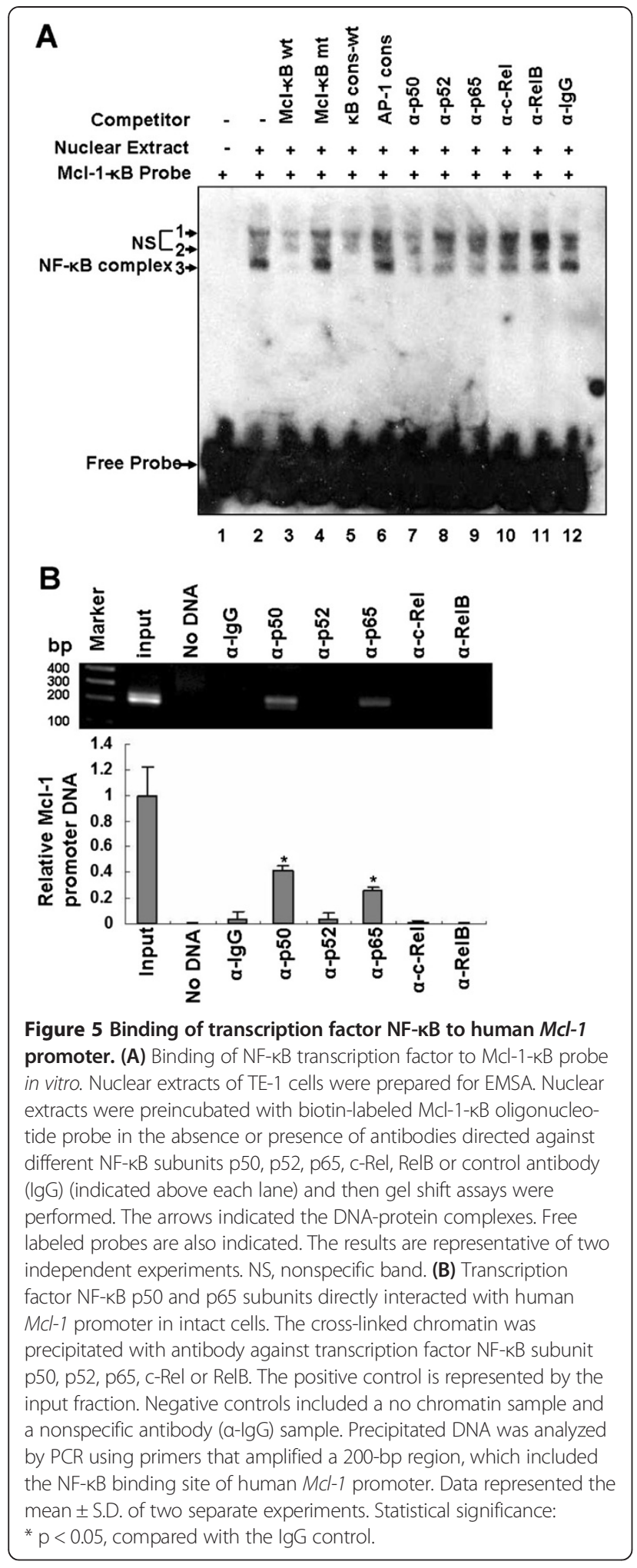

results suggested that the interaction of transcription factor NF-kB subunits p50 and p65 with human Mcl-1 promoter might be a key event in the regulation of Mcl1 expression in TE- 1 cells.
Knockdown of NF-KB subunit attenuates Mcl-1 expression and inhibits TE-1 cell viability

To further confirm the involvement of individual NF- $\mathrm{KB}$ subunits in Mcl-1 expression, we performed knockdown experiments. TE-1 cells were transfected with siRNAs to either p50, p65 or a scrambled control and then the Mcl-1 levels were assessed. To determine the optimal time point for analysis, a time-course experiment was performed at multiple time points after transfection. Representative time-course data of Mcl-1 reduced by p50 or p65 siRNA was shown in Figure 6A and B. The levels of endogenous p 50 and p 65 decreased by $24 \mathrm{~h}$ after transfection of si-p50 or si-p65 and peaked $72 \mathrm{~h}$, then gradually recovered with time. The Mcl-1 downregulation peaked $96 \mathrm{~h}$ after si-p50 transfection (Figure 6A) and peaked $72 \mathrm{~h}$ after si-p65 transfection (Figure 6B) and remained at relatively low levels $144 \mathrm{~h}$ posttransfection. Base on the timecourse data, the optimal protocol of $72 \mathrm{~h}$-treatment was used in subsequent experiments. Compared with the control siRNA, silencing of p50 or p65 each simultaneously led to a significant decrease of Mcl-1 protein levels (Figure 6C). With these data confirming the knockdown of NF- $\mathrm{kB}$ subunits and the downregulation of Mcl-1 expression, we next tested the effect of the NF$\kappa \mathrm{B}$ subunit siRNAs on TE-1 cell viability. Silencing of p50 or p65 resulted in decrease of Mcl-1 level (Figure 6D), which significantly inhibited the viability of TE-1 cells (Figure 6E). Reintroduction of human Mcl-1 (Figure 6D) significantly restored cell viability (Figure 6E), indicating that the specific reduction of Mcl-1 by p50 or p65 siRNA. Notably, cell viability was unable to be completely rescued even the Mcl-1 levels were totally recovered, suggesting other NF- $\mathrm{KB}$-dependent proteins might also contribute to TE-1 cell viability. These results suggest that NF- $\mathrm{KB}$ subtypes formed functional heterodimers mediating Mcl-1 expression and cell viability in TE-1 cells.

\section{Discussion}

Expression of Mcl-1 is frequently increased in various human tumors, so the mechanisms that increase Mcl-1 levels are of paramount importance. In addition to being modulated at transcriptional level by various transcription factors that bind and activate the $\mathrm{Mcl}-1$ promoter aforementioned, Mcl-1 could be regulated on multiple levels, such as translational and post-translational. For instance, E3 ubiquitin ligase Mule has been identified to required and sufficient for the polyubiquitination of Mcl-1. Elimination of Mule expression by RNA interference stabilizes Mcl-1 protein, resulting in an increase of Mcl-1 protein level [41]. Another E3 ligase $\beta$-TrCP facilitates the ubiquitination and degradation of GSK-3 3 -phosphorylated Mcl-1, which contributes to GSK-3 $\beta$-induced apoptosis [42]. Mutational inactivation 


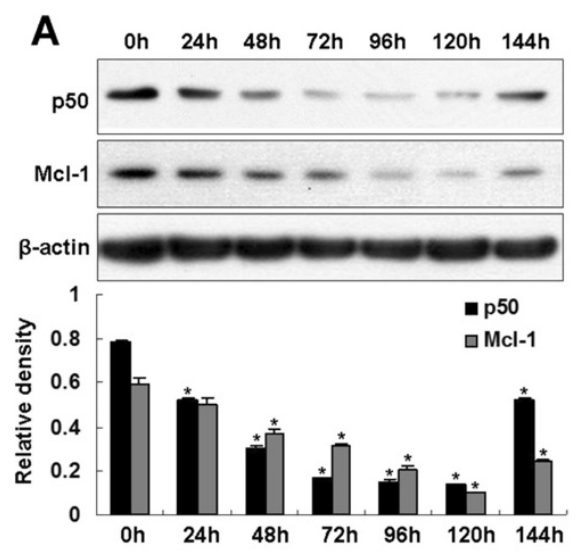

C

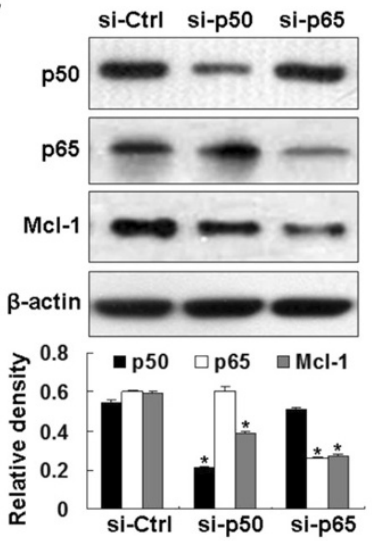

B $\quad$ oh $\quad 24 \mathrm{~h} \quad 48 \mathrm{~h} \quad 72 \mathrm{~h} \quad 96 \mathrm{~h} \quad 120 \mathrm{~h} 144 \mathrm{~h}$

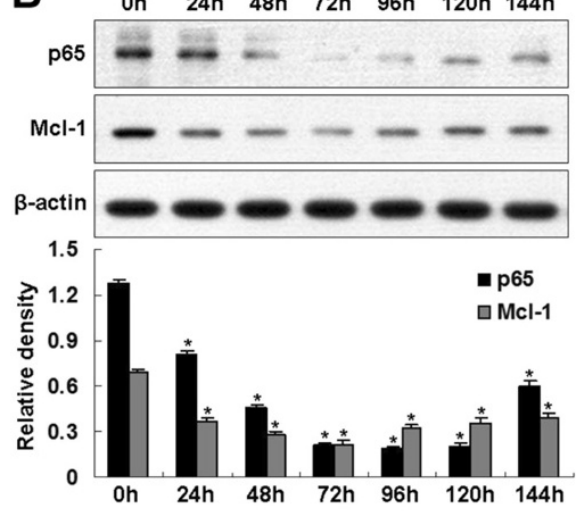

D

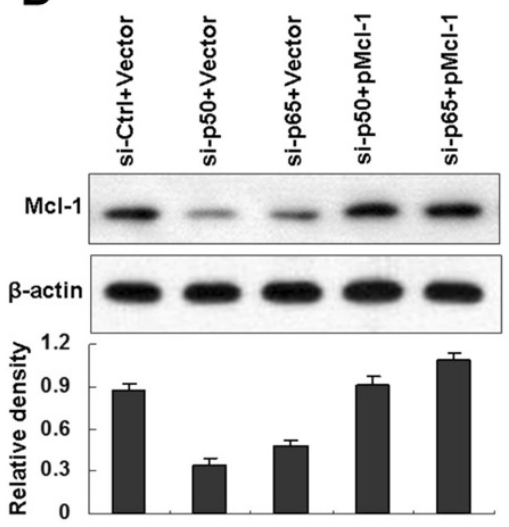

E

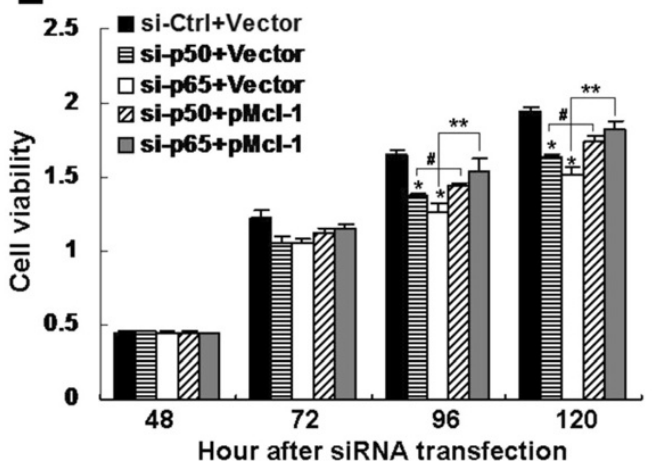

Figure 6 Inhibition of NF-KB subunit by siRNA downregulates Mcl-1 expression and suppresses the viability of TE-1 cells. (A, B) Time course experiments performed with p50 or p65 siRNA utilized. Representative Western blots of endogenous p50, p65 or Mcl-1expression in TE-1 cells at various time points following transfection with $100 \mathrm{nM}$ p50 (A) or p65 (B) siRNA. $\beta$-actin was used as a loading control. Data shown are representative of two independent experiments. Statistical significance: ${ }^{*} p<0.05$, compared with the siRNA-transfected TE-1 cells at 0 h. (C) Growing TE-1 cells were transiently transfected with $100 \mathrm{nM}$ of control, p50 or p65 siRNA and cultured in the medium for 72 h. Knockdown of endogenous p50 or p65 and expression of Mcl-1 were analyzed by Western blotting. $\beta$-actin was used as a loading control. Data represented the mean \pm S.D. of two separate experiments. Statistical significance: ${ }^{*} p<0.05$ compared with the si-Ctrl-transfected TE- 1 cells. (D, E) Reintroduction of Mcl-1 to Mcl-1-downregulated TE-1 cells caused by NF-KB subunit siRNA restored cell viability. TE-1 cells were sequentially transfected with NF-KB subunit siRNA and Mcl-1 expression plasmid as described in Methods. Cells were analyzed the Mcl-1 levels at $120 \mathrm{~h}$ after siRNA transfection by Western blotting (D) and measured cell viability by WST-1 assay at $24 \mathrm{~h}$-intervals up to $120 \mathrm{~h}$ after siRNA transfection (E). Data represented the mean \pm S.D. of two separate experiments. Statistical significance: ${ }^{*} p<0.05$, compared with the si-Ctrl and pCMV6-A-Puro empty vector co-transfected TE-1 cells. \# p < 0.05, compared the si-p50 and pCMV6-A-Puro empty vector co-transfected with the si-p50 and pCMV6-A-Puro-Mcl co-transfected TE-1 cells. ${ }^{* *} \mathrm{p}<0.05$, compared the si-p65 and pCMV6-A-Puro empty vector co-transfected with the si-p65 and pCMV6-A-Puro-Mcl co-transfected TE-1 cells. 
of E3 ligase FBW7 was found to occur in several neoplastic diseases, which can decrease Mcl-1 degradation, resulting in increased $\mathrm{Mcl}-1$ protein levels and resistance to chemotherapeutic agents [43]. In contrast, deubiquitinase USP9X, which is overexpressed in some malignancies, stabilizes Mcl-1 and promotes tumor cell survival. Knockdown of USP9X decreased Mcl-1 levels [5]. Moreover, phosphorylation of Mcl-1 at Thr 163 by ERK [43] prolongs the Mcl-1 half-life while phosphorylation at Thr 163 by GSK-3 $\beta$ [42] or Thr 92 by CDK1 [43] enhances Mcl-1 degradation. In addition, Mcl-1 transcripts can be influenced by microRNAs (miRs). For example, miR29b has been demonstrated to downregulate $\mathrm{Mcl}-1$ protein and sensitize cells to apoptosis [44]. Future studies need to explore whether these mechanisms contribute to the elevated $\mathrm{Mcl}-1$ protein in human ESCC.

Increased $\mathrm{Mcl}-1$ protein level has been reported to compromise the apoptotic effects of chemotherapeutic agents, resulting in therapeutic resistance [43]. Thus, the pathways that are critical for regulating Mcl-1 expression have been employed to target Mcl-1 for cancer therapy. For instance, in large granular lymphocyte leukemia, targeting Stat3 with its upstream kinase JAKselective inhibitor AG490 transcriptionally suppresses Mcl-1 and promotes apoptosis [12]. PI3K/Akt signaling is involved in Mcl-1 induction [10], targeting this pathway by newly developed PI3K inhibitor PI103 is showed to suppress $\mathrm{Mcl}-1$ and induced apoptosis and restore sensitivity to TRAIL-induced apoptosis in neuroblastoma [45]. Treatment with MEK/ERK inhibitor U0126 resulted in Mcl-1 downregulation and induced marked apoptosis in Mel-RM melanoma cells [46]. Therefore, identification of pathways that regulate $\mathrm{Mcl}-1$ may help to improve the therapeutic effect of chemotherapy. Our data indicated that inhibition of $N F-\kappa B$ pathway by Bay11-7082 (Figure 4A, B), DNMIkB $\alpha$ (Figure 4C, D) or NF- $\mathrm{kB}$ subunit siRNA (Figure 6) attenuates Mcl-1 expression in human ESCC cells. We also found that the survival of TE-1 cells is impaired when NF- $\mathrm{B}$ is blocked by expression of p50 siRNA or p65 siRNA and reintroduction of Mcl-1 to the siRNA-transfected TE-1 cells significantly restores cell viability (Figure 6E). These data that decrease $\mathrm{Mcl}-1$ expression and inhibits cell viability by inhibition of $\mathrm{NF}-\mathrm{kB}$ pathway support the use of selective NF- $\mathrm{kB}$ inhibitors in the treatment of Mcl-1overexpressing human ESCC.

By gel shift analysis, nuclear extracts of TE-1 cells were preincubated with antisera directed against individual NF-кB family members p50, p52, p65, c-Rel, RelB or with a nonspecific antisera prior to interaction with the Mcl-1-kB site probe. We found that NF- $\mathrm{B}$ family members p50, p52 and p65 were able to bind to the same probe in vitro. The result was in agreement with the earlier findings that most $\mathrm{\kappa} B$ sites show no or little selectivity for a given NF- $\mathrm{kB}$ species and different dimers have broad sequence recognition specificities although relatively small differences in the relative affinity of NF- $\mathrm{B}$ dimers for a given site can be found [47-49]. However, p50 and p65 but not p52 were revealed directly binding to the $\mathrm{kB}$ site of human $\mathrm{Mcl}-1$ promoter in intact cells by ChIP assays. The discrepancy between the measured in vitro affinity of $\mathrm{NF}-\kappa \mathrm{B}$ for the $\kappa \mathrm{B}$ probe and the real in vivo occupancy at $\kappa \mathrm{B}$ site of the natural promoter is not without precedent. For instance, ChIP result showed that, in LPS-stimulated DCs, the $\kappa \mathrm{B}$ site of $I L-8$ promoter is a highly selective p65 recruiter [50], while in in vitro experiments, it is bound and activated by both p65 and c-Rel homodimers [51]. The ability of a specific gene to selectively recruit various $N F-\kappa B$ dimers in vivo cannot be predicted on the basis of in vitro results [50]. The context of $\mathrm{kB}$ site physiological promoter rather than the $\mathrm{\kappa B}$ site itself is the major determinant of which NF- $\mathrm{B}$ dimmer will ultimately be loaded onto a certain promoter.

Although putative binding sites for NF- $\mathrm{kB}$ were identified in the $\mathrm{Mcl}-1$ promoter region [9] and two recent reports have shown that NF- $\mathrm{kB}$ is directly involved in Mcl-1 regulation $[17,18]$. In the first article, by using ChIP assay, the authors show that p65 subunit of NF-kB following TRAIL treatment binds to the $\mathrm{Mcl}-1$ promoter, which suggested that TRAIL induced expression of Mcl1 through activation of NF- $\mathrm{kB}$ in HCT-116 colon carcinoma cells [17]. In the second study, the authors show that transcriptional activation of $\mathrm{Mcl}-1$ gene required the recruitment of $\mathrm{N}$-a-Acetyltransferase 10 protein/p65 complex to the p65-binding site of the $\mathrm{Mcl}-1$ promoter region [18]. However, both studies focused only on the role of NF-kB p65 subunit in Mcl-1 expression and the report of other NF- $\mathrm{kB}$ subunits involved in Mcl-1 expression is relatively limited. Since dimerization is required for NF- $\mathrm{KB}$ binding to DNA and more than 12 homo- and heterodimers have been described [50]. The analysis of other members of the NF- $\mathrm{kB}$ family to bind to $\kappa \mathrm{B}$ site and regulate $\mathrm{Mcl}-1$ expression would allow for a better understanding of the precise mechanism of $\mathrm{Mcl}-1$ transcriptional control by NF- $\mathrm{kB}$. Our results indicate that effect of NF- $\mathrm{kB}$ on Mcl-1 expression in TE-1 cells is due to activation of NF- $\mathrm{kB}$ subtypes p65 and p50, without activation of other subtypes (Figure $5 \mathrm{~B}$ ) and reveal that activations of p65 and p50 are involved in Mcl-1 expression thus affecting cell viability (Figure 6E). Notably, we did not observe the involvement of NF- $\mathrm{BB}$ pathway in human $\mathrm{Mcl}-1$ promoter activity in Eca109 cells (Figure 3A). In addition to NF- $\mathrm{kB}$ binding site, the 325 bp long $\mathrm{Mcl}-1$ promoter fragment contains CRE-BP, Ets, Sp1, SRE, STAT binding sites [17,52]. We speculated that, in Eca109 cells, other transcription factor(s) rather than NF- $\mathrm{kB}$ might play a leading role in Mcl-1 expression. Our results suggested that the 
existence of other regulatory cascades that modulate Mcl-1 expression in different ESCC cells.

\section{Conclusions}

In summary, we provided evidence regarding how $\mathrm{Mcl}-1$ is regulated at transcription level in human ESCC cell lines. The present study demonstrated that NF- $\mathrm{kB}$ contributes to $\mathrm{Mcl}-1$ production in various human ESCC cells and subunits $\mathrm{p} 50$ and $\mathrm{p} 65$ of NF-kB positively regulate Mcl-1 expression and cell viability in TE-1 cells. The results support the conclusion that Mcl-1 plays a key role in mediating TE-1 cell fate downstream of the NF- $\mathrm{kB}$ pathway. The newly identified mechanism suggests that targeting the NF- $\mathrm{kB}$ pathway might improve treatment results in some human ESCCs with high Mcl-1 expression.

\section{Competing interests}

The authors declare that they have no competing interests.

\section{Authors' contributions}

HDL conceived the study, analyzed data and drafted the manuscript. JFY YCY acquired and analyzed data. ZKX MJC JW LX XLM acquired data. SFO QW provided material support. XMZ YFY FLY YC reviewed the manuscript. BLY JGH supervised the study, analyzed data and finalized the manuscript. All authors read and approved the final manuscript.

\section{Acknowledgements \\ We thank Dr. Qian Tao (Cancer Epigenetics Laboratory, Department of Clinical Oncology, The Chinese University of Hong Kong) for the gift of KYSE150 and KYSE510 cell lines. Dr. Chengchao Shou (Key Laboratory of Carcinogenesis and Translational Research, Department of Biochemistry and Molecular Biology Peking University Cancer Hospital \& Institute) is gratefully acknowledged for providing pCMV6-A-Puro vector and pCMV6-A-Puro-Mcl plasmids. This work was supported by the National Nature Science Foundation of China (\#30973399).}

\section{Author details}

'Department of Cardiothoracic Surgery, The Second Xiangya Hospital, Central South University, 139 Renmin Road, Changsha, Hunan 410011, China. ${ }^{2}$ Clinical Center for Gene Diagnosis and Therapy, The Second Xiangya Hospital, Central South University, 139 Renmin Road, Changsha, Hunan 410011, China. ${ }^{3}$ Cancer Research Institute, Xiangya School of Medicine, Central South University, 110 Xiangya Road, Changsha, Hunan 410078, China.

Received: 17 May 2013 Accepted: 11 February 2014

Published: 17 February 2014

\section{References}

1. Enzinger PC, Mayer RJ: Esophageal cancer. N Engl J Med 2003, 349:2241-2252.

2. Sieghart W, Losert D, Strommer S, Cejka D, Schmid K, Rasoul-Rockenschaub S, Bodingbauer M, Crevenna R, Monia BP, Peck-Radosavljevic M, Wacheck V: Mcl-1 overexpression in hepatocellular carcinoma: a potential target for antisense therapy. J Hepatol 2006, 44:151-157.

3. Miyamoto Y, Hosotani R, Wada M, Lee JU, Koshiba T, Fujimoto K, Tsuji S, Nakajima S, Doi R, Kato $\mathrm{M}$, et al: Immunohistochemical analysis of $\mathrm{BCl}-2$, Bax, BCl-X, and Mcl-1 expression in pancreatic cancers. Oncology 1999, 56:73-82.

4. Dash R, Richards JE, Su ZZ, Bhutia SK, Azab B, Rahmani M, Dasmahapatra G, Yacoub A, Dent P, Dmitriev IP, et al: Mechanism by which Mcl-1 regulates cancer-specific apoptosis triggered by mda-7/L-24, an IL-10-related cytokine. Cancer Res 2010, 70:5034-5045.

5. Schwickart M, Huang X, Lill JR, Liu J, Ferrando R, French DM, Maecker H, O'Rourke K, Bazan F, Eastham-Anderson J, et al: Deubiquitinase USP9X stabilizes MCL1 and promotes tumour cell survival. Nature 2010, 463:103-107.
6. Keuling AM, Felton KE, Parker AA, Akbari M, Andrew SE, Tron VA: RNA silencing of Mcl-1 enhances ABT-737-mediated apoptosis in melanoma: role for a caspase-8-dependent pathway. PLoS One 2009, 4:e6651.

7. Beroukhim R, Mermel CH, Porter D, Wei G, Raychaudhuri S, Donovan J, Barretina J, Boehm JS, Dobson J, Urashima M, et al: The landscape of somatic copy-number alteration across human cancers. Nature 2010, 463:899-905.

8. Placzek WJ, Wei J, Kitada S, Zhai D, Reed JC, Pellecchia M: A survey of the anti-apoptotic Bcl-2 subfamily expression in cancer types provides a platform to predict the efficacy of $\mathrm{Bcl}-2$ antagonists in cancer therapy. Cell Death Dis 2010, 1:e40.

9. Akgul C, Turner PC, White MR, Edwards SW: Functional analysis of the human MCL-1 gene. Cell Mol Life Sci 2000, 57:684-691.

10. Wang JM, Chao JR, Chen W, Kuo ML, Yen JJ, Yang-Yen HF: The antiapoptotic gene mcl-1 is up-regulated by the phosphatidylinositol 3-kinase/Akt signaling pathway through a transcription factor complex containing CREB. Mol Cell Biol 1999, 19:6195-6206.

11. Liu H, Ma Y, Cole SM, Zander C, Chen KH, Karras J, Pope RM: Serine phosphorylation of STAT3 is essential for Mcl-1 expression and macrophage survival. Blood 2003, 102:344-352.

12. Epling-Burnette PK, Liu JH, Catlett-Falcone R, Turkson J, Oshiro M, Kothapalli R, Li Y, Wang JM, Yang-Yen HF, Karras J, et al: Inhibition of STAT3 signaling leads to apoptosis of leukemic large granular lymphocytes and decreased Mcl-1 expression. J Clin Invest 2001, 107:351-362.

13. Townsend KJ, Zhou P, Qian L, Bieszczad CK, Lowrey CH, Yen A, Craig RW: Regulation of MCL1 through a serum response factor/Elk-1-mediated mechanism links expression of a viability-promoting member of the $\mathrm{BCL2}$ family to the induction of hematopoietic cell differentiation. J Biol Chem 1999, 274:1801-1813.

14. Wang JM, Lai MZ, Yang-Yen HF: Interleukin-3 stimulation of mcl-1 gene transcription involves activation of the PU.1 transcription factor through a p38 mitogen-activated protein kinase-dependent pathway. Mol Cell Biol 2003, 23:1896-1909.

15. Meinel FG, Mandl-Weber S, Baumann P, Leban J, Schmidmaier R: The novel, proteasome-independent NF-kappaB inhibitor V1810 induces apoptosis and cell cycle arrest in multiple myeloma and overcomes NF-kappaBmediated drug resistance. Mol Cancer Ther 2010, 9:300-310.

16. Reuter S, Prasad S, Phromnoi K, Ravindran J, Sung B, Yadav VR, Kannappan R, Chaturvedi MM, Aggarwal BB: Thiocolchicoside exhibits anticancer effects through downregulation of NF-kappaB pathway and its regulated gene products linked to inflammation and cancer. Cancer Prev Res (Phila) 2010, 3:1462-1472.

17. Ricci MS, Kim SH, Ogi K, Plastaras JP, Ling J, Wang W, Jin Z, Liu YY, Dicker DT, Chiao PJ, et al: Reduction of TRAIL-induced Mcl-1 and CIAP2 by c-Myc or sorafenib sensitizes resistant human cancer cells to TRAIL-induced death. Cancer Cell 2007, 12:66-80.

18. Xu H, Jiang B, Meng L, Ren T, Zeng Y, Wu J, Qu L, Shou C: N-alphaacetyltransferase 10 protein inhibits apoptosis through RelA/p65regulated MCL1 expression. Carcinogenesis 2012, 33:1193-1202.

19. Perkins ND: Integrating cell-signalling pathways with NF-kappaB and IKK function. Nat Rev Mol Cell Biol 2007, 8:49-62.

20. Perkins ND: Regulation of NF-kappaB by atypical activators and tumour suppressors. Biochem Soc Trans 2004, 32:936-939.

21. Sethi G, Sung B, Aggarwal BB: Nuclear factor-kappaB activation: from bench to bedside. Exp Biol Med (Maywood) 2008, 233:21-31.

22. Basseres DS, Baldwin AS: Nuclear factor-kappaB and inhibitor of kappaB kinase pathways in oncogenic initiation and progression. Oncogene 2006, 25:6817-6830.

23. Izzo JG, Malhotra U, Wu T, Ensor J, Luthra R, Lee JH, Swisher SG, Liao Z, Chao KS, Hittelman WN, et al: Association of activated transcription factor nuclear factor kappab with chemoradiation resistance and poor outcome in esophageal carcinoma. J Clin Oncol 2006, 24:748-754.

24. Tian F, Zang WD, Hou WH, Liu HT, Xue LX: Nuclear factor-kB signaling pathway constitutively activated in esophageal squamous cell carcinoma cell lines and inhibition of growth of cells by small interfering RNA. Acta Biochim Biophys Sin (Shanghai) 2006, 38:318-326.

25. Leu CM, Chang C, Hu C: Epidermal growth factor (EGF) suppresses staurosporine-induced apoptosis by inducing $\mathrm{mcl}-1$ via the mitogenactivated protein kinase pathway. Oncogene 2000, 19:1665-1675.

26. Feng YB, Lin DC, Shi ZZ, Wang XC, Shen XM, Zhang Y, Du XL, Luo ML, Xu X, Han YL, et al: Overexpression of PLK1 is associated with poor survival by 
inhibiting apoptosis via enhancement of survivin level in esophageal squamous cell carcinoma. Int J Cancer 2009, 124:578-588.

27. Boukamp P, Petrussevska RT, Breitkreutz D, Hornung J, Markham A, Fusenig NE: Normal keratinization in a spontaneously immortalized aneuploid human keratinocyte cell line. J Cell Biol 1988, 106:761-771.

28. Yang LF, Zhao Y, Zeng L, Gong JP, Cao Y: hTERT/re-caspase-3 system induce apoptosis in hTERT-positive cancer cells. Cancer Biol Ther 2006, 5:1546-1553.

29. Liu HD, Zheng H, Li M, Hu DS, Tang M, Cao Y: Upregulated expression of kappa light chain by Epstein-Barr virus encoded latent membrane protein 1 in nasopharyngeal carcinoma cells via NF-kappaB and AP-1 pathways. Cell Signal 2007, 19:419-427.

30. Liu H, Zheng H, Duan Z, Hu D, Li M, Liu S, Li Z, Deng X, Wang Z, Tang M, et al: LMP1-augmented kappa intron enhancer activity contributes to upregulation expression of Ig kappa light chain via NF-kappaB and APpathways in nasopharyngeal carcinoma cells. Mol Cancer 2009, 8:92.

31. Luo W, Yan G, Li L, Wang Z, Liu H, Zhou S, Liu S, Tang M, Yi W, Dong Z, Cao $Y$ : Epstein-Barr virus latent membrane protein 1 mediates serine 25 phosphorylation and nuclear entry of annexin A2 via PI-PLC-PKCalpha/ PKCbeta pathway. Mol Carcinog 2008, 47:934-946.

32. Liu H, Duan Z, Zheng H, Hu D, Li M, Tao Y, Bode AM, Dong Z, Cao Y: EBV-encoded LMP1 upregulates Igkappa 3'enhancer activity and Igkappa expression in nasopharyngeal cancer cells by activating the Ets-1 through ERKs signaling. PLoS One 2012, 7:e32624.

33. Rosato RR, Almenara JA, Kolla SS, Maggio SC, Coe S, Gimenez MS, Dent P, Grant S: Mechanism and functional role of XIAP and Mcl-1 downregulation in flavopiridol/vorinostat antileukemic interactions. Mol Cancer Ther 2007, 6:692-702.

34. Solanas G, Porta-de-la-Riva M, Agusti C, Casagolda D, Sanchez-Aguilera F, Larriba MJ, Pons F, Peiro S, Escriva M, Munoz A, et al: E-cadherin controls beta-catenin and NF-kappaB transcriptional activity in mesenchymal gene expression. J Cell Sci 2008, 121:2224-2234.

35. Wang X, Sonenshein GE: Induction of the RelB NF-kappaB subunit by the cytomegalovirus IE1 protein is mediated via Jun kinase and c-Jun/Fra-2 AP-1 complexes. J Virol 2005, 79:95-105.

36. Sohda M, Mochida Y, Kato H, Miyazaki T, Nakajima M, Fukuchi M, Manda R, Fukai Y, Masuda N, Ono M, et al: Overexpression of Cap43 is associated with malignant status of esophageal cancer. Anticancer Res 2009, 29:965-970.

37. Yan S, Zhou C, Zhang W, Zhang G, Zhao X, Yang S, Wang Y, Lu N, Zhu H, Xu N: beta-Catenin/TCF pathway upregulates STAT3 expression in human esophageal squamous cell carcinoma. Cancer Lett 2008, 271:85-97.

38. Li Y, Reddy MA, Miao F, Shanmugam N, Yee JK, Hawkins D, Ren B, Natarajan R: Role of the histone H3 lysine 4 methyltransferase, SET7/9, in the regulation of NF-kappaB-dependent inflammatory genes. Relevance to diabetes and inflammation. J Biol Chem 2008, 283:26771-26781.

39. Huang C, Bi E, Hu Y, Deng W, Tian Z, Dong C, Hu Y, Sun B: A novel NF-kappaB binding site controls human granzyme $B$ gene transcription. J Immunol 2006, 176:4173-4181.

40. Beverly LJ, Capobianco AJ: Targeting promiscuous signaling pathways in cancer: another Notch in the bedpost. Trends Mol Med 2004, 10:591-598.

41. Zhong Q, Gao W, Du F, Wang X: Mule/ARF-BP1, a BH3-only E3 ubiquitin ligase, catalyzes the polyubiquitination of $\mathrm{Mcl}-1$ and regulates apoptosis. Cell 2005, 121:1085-1095

42. Ding Q, He X, Hsu JM, Xia W, Chen CT, Li LY, Lee DF, Liu JC, Zhong Q, Wang $X$, Hung MC: Degradation of Mcl-1 by beta-TrCP mediates glycogen synthase kinase 3-induced tumor suppression and chemosensitization. Mol Cell Biol 2007, 27:4006-4017

43. Wertz IE, Kusam S, Lam C, Okamoto T, Sandoval W, Anderson DJ, Helgason E, Ernst JA, Eby M, Liu J, et al: Sensitivity to antitubulin chemotherapeutics is regulated by MCL1 and FBW7. Nature 2011, 471:110-114.

44. Mott JL, Kobayashi S, Bronk SF, Gores GJ: mir-29 regulates Mcl-1 protein expression and apoptosis. Oncogene 2007, 26:6133-6140.

45. Opel D, Naumann I, Schneider M, Bertele D, Debatin KM, Fulda S: Targeting aberrant PI3K/Akt activation by PI103 restores sensitivity to TRAILinduced apoptosis in neuroblastoma. Clin Cancer Res 2011, 17:3233-3247.

46. Wang YF, Jiang CC, Kiejda KA, Gillespie S, Zhang XD, Hersey P: Apoptosis induction in human melanoma cells by inhibition of MEK is caspaseindependent and mediated by the Bcl-2 family members PUMA, Bim, and Mcl-1. Clin Cancer Res 2007, 13:4934-4942.
47. Udalova IA, Mott R, Field D, Kwiatkowski D: Quantitative prediction of NFkappa B DNA-protein interactions. Proc Natl Acad Sci U S A 2002, 99:8167-8172

48. Hoffmann A, Leung TH, Baltimore D: Genetic analysis of NF-kappaB/Rel transcription factors defines functional specificities. Embo J 2003, 22:5530-5539.

49. Natoli G, Saccani S, Bosisio D, Marazzi I: Interactions of NF-kappaB with chromatin: the art of being at the right place at the right time. Nat Immunol 2005, 6:439-445.

50. Saccani S, Pantano S, Natoli G: Modulation of NF-kappaB activity by exchange of dimers. Mol Cell 2003, 11:1563-1574.

51. Kunsch C, Rosen CA: NF-kappa B subunit-specific regulation of the interleukin-8 promoter. Mol Cell Biol 1993, 13:6137-6146.

52. Moshynska O, Sankaran K, Pahwa P, Saxena A: Prognostic significance of a short sequence insertion in the MCL-1 promoter in chronic lymphocytic leukemia. J Natl Cancer Inst 2004, 96:673-682.

doi:10.1186/1471-2407-14-98

Cite this article as: Liu et al.: Regulation of Mcl-1 by constitutive activation of NF-kappaB contributes to cell viability in human esophageal squamous cell carcinoma cells. BMC Cancer 2014 14:98,

\section{Submit your next manuscript to BioMed Central and take full advantage of:}

- Convenient online submission

- Thorough peer review

- No space constraints or color figure charges

- Immediate publication on acceptance

- Inclusion in PubMed, CAS, Scopus and Google Scholar

- Research which is freely available for redistribution 